\title{
O CARÁTER SIMBÓLICO DO CRIME DE SONEGAÇÃO DE CONTRIBUIÇÃO
} PREVIDENCIÁRIA

\author{
SYMBOLIC CHARACTER OF PENALTY OF SOCIAL SECURITY \\ CONTRIBUTION EVASION CRIME
}

\author{
${ }^{1}$ Candida Dettenborn Nóbrega \\ ${ }^{2}$ Nayara Gallieta Borges
}

\section{RESUMO}

A Previdência Social possui "regime geral, de caráter contributivo e de filiação obrigatória, observados critérios que preservem o equilíbrio financeiro e atuarial", com custeio, mormente, por contribuições sociais, que não repassadas configuram os crimes tipificados no art. 168-A (apropriação indébita previdenciária) e 337-A (sonegação de contribuição previdenciária) do Código Penal. A necessidade da tutela penal no crime de sonegação de contribuição previdenciária diante da extinção de punibilidade pelo pagamento do débito levanta a hipótese de legitimidade (ou não) da criminalização da conduta pelo caráter meramente simbólico da pena, e seu cunho arrecadatório, violando a noção de direito penal mínimo.

Palavras-chave: Crime; Sonegação de Contribuição Previdenciária; Caráter Simbólico da pena.

\begin{abstract}
Social Security has "general arrangements, of contributive character and compulsory membership, observed criteria that preserve financial and actuarial balance", with defrayment, mainly, by social contributions, if not forwarded, configures crimes typified in art. 168-A (social security misappropriation of funds) and 337-A (evasion crime of social security contributions) of Penal Code. The need of incidence by penal punishment in withholding crime of social security contributions face of extinction of criminal liability for the payment of debt comes up the legitimacy (or not) of criminalize this behavior by symbolism of the penalty, and levy aspect, and minimal criminal law idea.
\end{abstract}

Keywords: Crime; Evasion crime of Social Security Contributions; Symbolic character of penalty.

\footnotetext{
${ }^{1}$ Mestranda em Direito no Centro Universitário de Brasília, UniCEUB/ULBRA - DF, (Brasil). Advogada. Email: candidaadv1@ hotmail.com

${ }^{2}$ Mestranda em Direito e Políticas Públicas no MINTER do Centro Universitário de Brasília, UniCEUB/ULBRA - DF, (Brasil). E-mail: nayaragborges@gmail.com
} 


\section{INTRODUÇÃO}

A seguridade social engloba a previdência social, assistência social e a saúde, sendo um conjunto integrado de ações de iniciativa dos poderes públicos e da sociedade, conforme disposto no art. 194 da Constituição Federal - CF. A Previdência Social segundo a CF possui "regime geral, de caráter contributivo e de filiação obrigatória, observados critérios que preservem o equilíbrio financeiro e atuarial” (BRASIL, 2016a, online). O objetivo do sistema é suprir as necessidades básicas do ser humano, observado o equilíbrio atuarial dele. O custeio desse sistema se dá, mormente, por meio de espécie do gênero tributo, isto é, as contribuições sociais.

As contribuições são espécies de tributos vinculados a uma contraprestação estatal (ATALIBA, 1999, p. 183), que possuem uma destinação específica da arrecadação. Nesse gênero encontram-se as contribuições previdenciárias destinadas ao custeio da Previdência Social. Quando tais contribuições não são repassadas à previdência social, lesando seus cofres e sua função social, restam configurados crimes tipificados no art. 168-A (apropriação indébita previdenciária) e 337-A (sonegação de contribuição previdenciária) do Código Penal.

O Estado intervém na vida social por meio do Direito Penal e deve nele sintetizar o Estado de Direito, com sua prevenção especial ressocializante e as exigências da prevenção geral, por outro. Significa dizer que pensar no Direito Penal na atualidade é, justamente, definir o sentido e função da pena em cada caso (SUXBERGER, 2005, p. 122). Nesse contexto, cabe uma análise sobre se as condutas descritas no crime de sonegação de contribuição previdenciária mereceriam tratamento específico pelo Direito Penal, ou, se as normas penais anteriores com suas previsões genéricas eram suficientes para proteger tais interesses.

Existe uma incapacidade no sistema de seguridade social brasileiro de suprir as necessidades de todos os indivíduos, por diversos motivos, dentre eles o sistema de custeio. Inobstante, fatos notórios como a demora na concessão de benefícios, os complicados cálculos aritméticos utilizados, greves de servidores, notícias de fraudes, entre outros, são desconsideradas. Tudo isso contribui para o descrédito do funcionamento do sistema e aumento na inadimplência dos contribuintes, sendo automática a ponderação quanto à necessidade da tutela da seguridade social pelo Direito Penal. 
O esboço inicia com a análise da tutela penal da previdência social passando pela extinção da punibilidade no crime de sonegação de contribuição previdenciária e finalizando nas ponderações acerca da adequação e necessidade da tutela penal neste crime. Para este estudo, utiliza-se o método hipotético-dedutivo.

O principal questionamento envolve a legitimidade da criminalização da conduta de sonegação de contribuição previdenciária, se não se trataria de mero instrumento simbólico para punir infração administrativa. Destarte, avalia-se, em razão de política criminal, o tratamento dado pelo legislador ordinário à extinção da punibilidade para esse crime, pois medidas de caráter penal com cunho meramente arrecadatório, estimulam a seguinte reflexão: no que consiste a pretensão punitiva estatal? É ela legítima?

Frisa-se o crime de sonegação de contribuição previdenciária, visto que, nem toda a Seguridade é alcançada pela tutela penal dessas contribuições. Os crimes em questão são típicos delitos fiscais, razões político-criminais que se misturam com política fiscal até pela dificuldade de prova da materialidade e configuração do delito caso fosse apurado somente pelo fisco.

Ocorre que o tratamento dado pela Lei 10. 684/03 para a extinção da punibilidade nos crimes previdenciários pelo pagamento do débito acaba demonstrando interesse meramente arrecadatório que não condiz com a satisfação plena dos fins preventivos (gerais e especiais) da sanção penal. Cabe lembrar que a Seguridade Social é um instrumento de política pública fundado na dignidade humana e que almeja sua concretização, e a criminalização inefetiva de condutas não corresponde a esse fundamento, conforme será exposto no presente artigo.

\section{TUTELA PENAL DA PREVIDÊNCIA SOCIAL}

A tutela penal do tributo existe antes mesmo da ideia de direitos difusos e coletivos. Beccaria já previa que era necessário punir certas condutas atentatórias contra o fisco: "há contrabandos que interessam de tal forma à natureza do imposto, parte essencial e difícil da boa legislação, que esse delito merece severíssima pena, até prisão e escravidão, mas prisão e escravidão adequadas à natureza do delito" (BECCARIA, 1997, p. 113).

Ocorre que o tratamento jurídico-penal do fraudador do Fisco sempre teve uma abordagem político-criminal peculiar, pois, muitas vezes, a finalidade legislativa que se 
evidenciou é a de restauração do status quo ante, com a reparação do prejuízo causado, do que propriamente punir o autor de um fato delituoso. Conforme disposto na Constituição Federal, a previdência social faz parte de um sistema denominado seguridade social, mantido por diversas bases de financiamento, dentre elas as contribuições dispostas no art. 195 da CF (BRASIL, 2016a, online), vejamos:

Art. 195. A seguridade social será financiada por toda a sociedade, de forma direta e indireta, nos termos da lei, mediante recursos provenientes dos orçamentos da União, dos Estados, do Distrito Federal e dos Municípios, e das seguintes contribuições sociais:

I - do empregador, da empresa e da entidade a ela equiparada na forma da lei, incidentes sobre:

a) a folha de salários e demais rendimentos do trabalho pagos ou creditados, a qualquer título, à pessoa física que lhe preste serviço, mesmo sem vínculo empregatício;

b) a receita ou o faturamento;

c) o lucro;

II - do trabalhador e dos demais segurados da previdência social, não incidindo contribuição sobre aposentadoria e pensão concedidas pelo regime geral de previdência social de que trata o art. 201;

III - sobre a receita de concursos de prognósticos.

IV - do importador de bens ou serviços do exterior, ou de quem a lei a ele equiparar.

Por meio deste dispositivo resta embasada a criminalização da sonegação nas contribuições previdenciárias, pois determinou a obrigação previdenciária e delimitou os sujeitos passivos da obrigação. Inobstante, constitucionalizou-se a imprescindibilidade do equilíbrio financeiro e atuarial do sistema por meio de aporte de recursos, garantido inclusive, pela criminalização das condutas que esvaziem a arrecadação.

$\mathrm{Na}$ sociedade de massa, em que determinadas atitudes podem violar bem de titularidade difusa, evidencia-se a necessidade da tutela de bens jurídicos distintos dos bens tradicionais do direito penal, por quê:

A função precípua do Direito Penal é a proteção de bens jurídico-penais indispensáveis ao indivíduo e à sociedade, sendo que tal tutela deverá observar os princípios fundamentais da legalidade, da personalidade e individualização da pena, da humanidade, da insignificância, da culpabilidade e da intervenção mínima (ANDRADE, 2008, p. 85).

As contribuições previdenciárias são espécie do gênero tributo, sendo que "com o advento da Constituição de 1988, a natureza tributária das contribuições a que se refere o seu art. 149 - das quais a seguridade social fazem parte - é reconhecida tanto pela jurisprudência como pela maioria da doutrina” (PIERDONÁ, 2003, p. 21). 
Certo é que o custeio da previdência engloba a contribuição do empregado, descontada pelo empregador, e a contribuição do próprio empregador, ambas repassadas por ele aos cofres públicos. Seja pelo caráter preventivo, didático ou repressivo, os crimes previdenciários estão tipificados no Código Penal e sua tutela resta embasada no bem jurídico resguardado, sendo este as contribuições para a previdência social, ou numa observação mais percuciente, as funções que a previdência social desempenha. Desta feita, argumenta Rodrigo Sánches Rios:

\begin{abstract}
Ao partir do conceito de bem jurídico como "unidade funcional", de Jakobs, explica ser possível ao Estado punir condutas fraudulentas nas prestações públicas que visem obstaculizar o cumprimento de suas funções: "o Direito Penal passa pois a tutelar funções, reforçando penalmente valores coletivos (como o meio ambiente, a saúde, a ordem econômica etc.)". No entanto, essa construção de bem jurídico como função não é automática, nem tampouco fácil de compreendê-la. Desta forma, a justificação do crime fiscal encontra-se no fato de que a conduta delituosa, além de causar um prejuízo imediato à integridade patrimonial do Erário Público (lesando a função pública de arrecadação), acaba por atingir o valor constitucional da solidariedade de todos os cidadãos, na contribuição da manutenção dos gastos públicos. Este bem jurídico, 'representado' nas funções que o tributo deve exercer de acordo com os dispositivos constitucionais, justifica amplamente sua incriminação (RIOS, 1998, p. 41 e 50).
\end{abstract}

A Previdência está sujeita a uma variedade de crimes contra si, entretanto, é tutelada especificamente quanto aos atos atentatórios às contribuições sociais (arts. 168-A e 337-A do Código Penal) (BRASIL, 2016b, online).

A Lei 9. 983, publicada em 14.07.2000, entrou em vigência 90 dias depois. Revogou expressamente o art. 95 da Lei 8.212/91 e inseriu, no Código Penal, os arts. 168-A e 337-A, revogando também, o art.1 ${ }^{\circ}$, inc. I, da Lei 8.137/90, no que se refere às contribuições sociais. Além disso, criou figuras típicas novas, como o art. 313-A (inserção de dados falsos no sistema de informações), art.313-B (modificação ou alteração não autorizada de sistema de informações); e alterou tipos já existentes (arts. 153, 296, 397, 325 e 327), todos do Código Penal. Dessa forma, observa-se a existência de uma tutela penal específica da Previdência Social.

\title{
3 CRIMES PREVIDENCIÁRIOS
}


No estudo dos crimes contra a previdência social, compete descobrir qual é o bem jurídico em destaque, posto que ele se propõe a definir o sentido do Direito Penal e o que ele pretende proteger, de forma a limitar o seu âmbito de atuação e não consistir em um instrumento arbitrário.

Sob a perspectiva da Política Criminal, a noção de bem jurídico-penal é de capital relevância para a definição dos rumos do Direito Penal, principalmente em tempos de construção oportunista das normas repressivas que leva o sistema penal a representar cada vez mais fortemente o papel de instrumento de terror posto pelo Estado para exercício do controle e poder social, arruinando o tão bem demoradamente arquitetado sistema de direitos e garantias individuais e coletivos ao longo dos séculos (Lopes, 2000, p. 287).

A função precípua da determinação do bem jurídico é definir, dentre as formas que a conduta apresenta, qual exige uma repressão que necessite de sanção penal, o que visa garantir que "o Direito Penal consista em via de ultima ratio do ordenamento jurídico" (CASAGRANDE, 2010, p. 27).

A leitura sobre a importância do bem jurídico para a sociedade requer uma análise valorativa, externa ao Direito Penal, sob pena de o intérprete satisfazer-se com a legitimação estritamente interna (SUXBERGER, 2005, p. 6) e da justificação da intervenção penal por ela mesma. Observando-se a política criminal dos últimos quarenta anos no Brasil, verifica-se uma confusão entre o seu conteúdo de justiça e a sua mera existência como técnica autoreferencial de defesa e controle social (Idem, p. 8-9).

O Direito Penal deve selecionar com cautela o bem jurídico a ser criminalizado, de acordo com o princípio da dignidade da pessoa humana como vetor punitivo do Estado. A Constituição Federal hoje cumpre com a relevante função de publicização de valores estabelecidos por consenso na sociedade, inclusive para o Estado. A Constituição emana diretrizes para todo o ordenamento jurídico, inclusive para o direito penal. O núcleo base, ou o valor jurídico mais importante estabelecido pela Constituição é a dignidade da pessoa humana.

É dizer que o Direito Penal merece uma análise sobre a real necessidade da tutela penal: é a conjugação da dignidade do bem jurídico e da ofensividade da conduta (BIANCHINI, 2002). A arrecadação fiscal, por exemplo, como fomento da justiça social por envolver um conjunto de ações em benefício de toda a sociedade, é passível de ser considerada um bem jurídico penal.

Ocorre que não existe consenso entre os doutrinadores quanto ao bem jurídico tutelado nos crimes contra a previdência social e, mormente, quanto à sonegação. É compreensível, 
posto que a norma penal que instituiu a sonegação de contribuição previdenciária (art. 337-A) é tida como norma penal em branco, pois a incriminação é abstrata, sendo a conduta delitiva detalhada e integrada no Direito Previdenciário.

Neste sentido, são tidos como bens jurídicos dos crimes contra a seguridade social:

O patrimônio da previdência social, o patrimônio dos cidadãos ligados à previdência social; a ordem tributária; o bom andamento da Administração; os interesses estatais ligados à arrecadação das contribuições previdenciárias e seus acessórios; a "saúde financeira" da seguridade social; o interesse fisco-patrimonial dos órgãos públicos gestores da previdência social; o equilíbrio econômico-financeiro do sistema de seguridade social, a livre concorrência entre as empresas e, por derradeiro, os segurados e beneficiários que tiverem dificuldade em comprovar o período e o valor de suas contribuições (CASAGRANDE, 2008, p. 38).

O crime de apropriação indébita previdenciária foi inserido no Código Penal entre os crimes contra o patrimônio. Já o de sonegação de contribuição previdenciária entre os crimes contra a Administração Pública. Há o entendimento de que não se pode considerar o patrimônio público como bem jurídico nos crimes contra a seguridade social (CASAGRANDE, 2010, p. 33), da mesma forma entendimento distinto ${ }^{3}$.

Dentre os diversos entendimentos acerca do bem jurídico nos crimes de sonegação de contribuição previdenciária objeto do presente estudo, a conclusão que se mostra mais acertada é aquela segundo a qual o que se visa realmente proteger através do Direito Penal é a arrecadação para a seguridade social, mormente, para a previdência social. Nesse sentido, Casagrande preleciona que o bem jurídico protegido pelo artigo 337-A não é o patrimônio da Seguridade Social, mas os interesses estatais ligados à arrecadação das contribuições previdenciárias e seus acessórios, devidos à Previdência Social (INSS) e não ao conjunto integrado de ações que compõe a Seguridade Social, visando à boa execução das políticas sociais e do custeio e da manutenção do sistema de aposentadorias, auxílios em geral e outros benefícios. Protege, principalmente, a Administração Pública (CASAGRANDE, 2010, p. 39).

Assim, afirmar que o bem jurídico protegido pelos crimes ora estudados é a seguridade social seria pecar por conclusão vaga. Em sentido diverso aduz Wagner Balera que "o objeto jurídico tutelado será (...) o equilíbrio econômico financeiro do sistema de seguridade social

\footnotetext{
${ }^{3}$ (...) Ao reprimir penalmente a sonegação de contribuição previdenciária, o legislador, objetivando assegurar o cumprimento das prestações públicas por parte do Estado, especificamente na área previdenciária, protege o patrimônio do ente público, dotado de capacidade ativa para arrecadar tal contribuição, já que quando esse direito é frustrado pela sonegação perpetrada pelo agente há um dano ao patrimônio daquele (Idem, p. 538).
} 
que será abalado pela ausência de recolhimento, na época própria, das contribuições sociais, em prejuízo de toda a sociedade" (PRADO, 2006, p. 538).

Há de se esclarecer que "efetivado o pagamento da quantia apropriada ou sonegada, a arrecadação resta intocada, pois se recompõe a inicial expectativa de receita do órgão público (arrecadação). Por benesse legal, de questionável virtude, fica, assim, extinta a punibilidade do autor do fato ${ }^{4}$.

Dessa feita, tem-se na arrecadação para a seguridade social o bem jurídico tutelado pelas normas dispostas nos artigos 168-A e 337-A do Código Penal, o primeiro dispositivo discorre sobre a apropriação indébita previdenciária e o segundo acerca da sonegação de contribuição previdenciária, seu conteúdo explicita (BRASIL, 2016b, online):

\footnotetext{
Art. 337-A. Suprimir ou reduzir contribuição social previdenciária e qualquer acessório, mediante as seguintes condutas:

I - omitir de folha de pagamento da empresa ou de documento de informações previsto pela legislação previdenciária segurados empregado, empresário, trabalhador avulso ou trabalhador autônomo ou a este equiparado que lhe prestem serviços;

II - deixar de lançar mensalmente nos títulos próprios da contabilidade da empresa as quantias descontadas dos segurados ou as devidas pelo empregador ou pelo tomador de serviços;

III - omitir, total ou parcialmente, receitas ou lucros auferidos, remunerações pagas ou creditadas e demais fatos geradores de contribuições sociais previdenciárias:

Pena - reclusão, de 2 (dois) a 5 (cinco) anos, e multa.

$\S 1$ Ó extinta a punibilidade se o agente, espontaneamente, declara e confessa as contribuições, importâncias ou valores e presta as informações devidas à previdência social, na forma definida em lei ou regulamento, antes do início da ação fiscal.

$\S 2$ é É facultado ao juiz deixar de aplicar a pena ou aplicar somente a de multa se o agente for primário e de bons antecedentes, desde que:

I - (VETADO)

II - o valor das contribuições devidas, inclusive acessórios, seja igual ou inferior àquele estabelecido pela previdência social, administrativamente, como sendo o mínimo para o ajuizamento de suas execuções fiscais.

$\S 3$ Se o empregador não é pessoa jurídica e sua folha de pagamento mensal não ultrapassa $\mathrm{R} \$ 1.510,00$ (um mil, quinhentos e dez reais), o juiz poderá reduzir a pena de um terço até a metade ou aplicar apenas a de multa.

$\S 4^{\circ} \mathrm{O}$ valor a que se refere o parágrafo anterior será reajustado nas mesmas datas e nos mesmos índices do reajuste dos benefícios da previdência social.
}

Como o artigo acima transcrito contém norma penal em branco, algumas expressões que integram o tipo penal deverão ser analisadas com base em elementos externos. O conceito de acessórios, por exemplo, está disposto no Código Tributário Nacional (CTN) no art. 133

\footnotetext{
${ }^{4}$ CASAGRANDE, Daniel Alberto. Crimes contra a arrecadação da seguridade social: apropriação indébita previdenciária e sonegação de contribuição previdenciária. São Paulo: Verbatim, 2010. P. 41.
} 
(BRASIL, 2016c, online), entendendo como obrigação principal a que surge com a ocorrência do fato gerador, tem por objeto o pagamento de tributo ou penalidade pecuniária e extingue-se juntamente com o crédito dela decorrente.

A obrigação acessória, por sua vez, decorre da legislação tributária cujo objeto são as prestações, positivas ou negativas, nela previstas no interesse da arrecadação ou fiscalização dos tributos e abrangem os juros, multas e atualização monetária do quantum devido.

A expressão "empresa” compreende, nos termos do inciso I, art. 15 da Lei n 8.212/91, uma "firma individual ou sociedade que assume o risco de atividade econômica urbana ou rural, com fins lucrativos ou não, bem como os órgãos e entidades da Administração Pública direta, indireta ou fundacional" (BRASIL, 2016d, online).

Já a expressão fato gerador é dada pelo art. 114 do CTN, sendo situação definida em lei como necessária e suficiente ao nascimento da obrigação tributária. Trata-se de crime material, pois necessita da verificação do resultado, qual seja, a frustração da arrecadação. Ora, ocorrido o fato gerador, nasce à expectativa de arrecadação que, se frustrada, resulta em diminuição de recursos para a seguridade social.

O elemento subjetivo do tipo é o dolo. A conduta é omissiva, vez que o crime se perpetra não recolhendo as contribuições, sendo que os verbos e locuções do tipo são omitir e deixar de lançar: são, portanto, inações. O crime é de natureza complexa e, para caracterização, exige além da dívida, a fraude. O sujeito ativo é o empregador ou tomador de serviços e o objeto material do crime é a contribuição social previdenciária e seus acessórios. Alguns apontam também como objeto material a folha de pagamento ou documento de informações e os títulos próprios da contabilidade da empresa.

O crime de sonegação de contribuição previdenciária exige uma conduta pré-ordenada que prepara e possibilita tenha sucesso a sonegação, devendo o agente praticar um falso ideológico, seja na omissão de dados na folha de pagamentos, deixar de lançar dados das quantias descontadas dos segurados ou devidas por si ou, ainda, omitindo total ou parcialmente receitas, lucros auferidos, remunerações pagas ou creditadas ou demais fatos geradores da contribuição.

Assim, nesse crime há "vontade de iludir os órgãos de fiscalização, omitindo informações que possibilitem auferir o real” (CASAGRANDE, Op. Cit., p. 180). Com relação aos delitos previdenciários, incluindo a sonegação de contribuição previdenciária, a detecção 
da materialidade do fato criminoso não é complexa, pode ser realizada por meio de fiscalização mensal pelo órgão arrecadador, verificando, por exemplo, a folha de pagamento das empresas, conferindo aos valores descontados com os recolhidos à previdência em guia própria, trabalho que realizar-se-á por auditor fiscal do trabalho. Mas os trabalhadores e o sindicato podem realizar sua fiscalização cobrando a apresentação dos comprovantes de pagamento das contribuições.

As condutas descritas no art. 337-A do Código Penal são omissivas e atentatórias à arrecadação das contribuições previdenciárias que não são direcionadas, como no art. 168-A, à figura do responsável tributário ou instituição conveniada responsável por repassar valores ao INSS. Em outro sentido, a finalidade do crime engloba alcançar o próprio contribuinte que ao praticar qualquer espécie de falsidade ideológica, objetive a redução ou supressão da contribuição social devida.

De forma diversa dos crimes taxados no art. 168-A do Código Penal exigem a supressão ou redução de contribuição social como resultado, tratando-se conforme já exposto, de crime omissivo por comissão. No crime de sonegação do art. 337-A do Código Penal, a conduta tem como objeto material a contribuição social previdenciária, ou seja, as devidas pelo empregado e pelo empregador oriundas das folhas de salários (art.167 da Constituição Federal) e para a consumação faz-se necessária confirmação de prejuízo aos cofres da Previdência.

\section{EXTINÇÃO DA PUNIBILIDADE NO CRIME DE SONEGAÇÃO DE CONTRIBUIÇÃO PREVIDENCIÁRIA}

O direito concreto do Estado de aplicar a pena denomina-se punibilidade (enquanto aplicabilidade da pena (PRADO, 2000, p. 440). A punibilidade envolve as circunstâncias exteriores ao crime, sendo que, nas lições de João Mestieri, “delito é ação humana, típica e culpável. Punibilidade não é elemento constitutivo do crime, mas consequência de se reconhecer presentes os seus elementos constitutivos" (MESTIERI, 1999, p. 315). Nesse sentido: 
A punibilidade é consequência do crime, não podendo ser considerada um seu elemento (...). Elemento é uma condição necessária à existência de todo o fenômeno, sendo, portanto, algo que o precede. A punibilidade, ao contrário, é um posterius com relação ao crime, do qual se origina. Praticada a ação delituosa surge o direito subjetivo do Estado de impor a sanção ao infrator, direito que se expressa na chamada pretensão punitiva (COSTA JR., 2004, p. 283).

Nesse aspecto, as causas de extinção da punibilidade seriam hipóteses legais impeditivas da punibilidade, mesmo diante da consecução do delito. Assim, o direito do Estado de punir não se concretiza pela configuração de causa extintiva. Há quem entenda que “o Direito Penal brasileiro, em alguns casos, passou a adotar para crimes que envolvam quantias patrimoniais a extinção da punibilidade pelo pagamento, com o que se recompõe a situação monetária do sujeito passivo, como se a conduta delituosa não tivesse existido" (CASAGRANDE, Op. Cit., p. 62).

Os REFIS I, II e III (leis no 9.964/00, n 10.684/03 e medida provisória no 303/06) são exemplos de aplicação da extinção da punibilidade dos crimes em comento. Rodrigo Sanches Ríos argumenta que "a raiz do instituto da extinção da punibilidade pelo pagamento do crédito tributário encontra-se no ordenamento jurídico alemão. Referido instituto, naquele país é denominado autodenúncia liberadora da pena” (RIOS, Op. Cit., p. 138). No crime de sonegação de contribuição previdenciária a simples declaração e confissão dos valores devidos já extingue a punibilidade, independentemente do pagamento.

Com a edição da Lei $n^{\circ}$ 9.983/00, que alterou o Código Penal, inserindo os arts. 168-A e 337-A, em relação ao primeiro delito possibilitou a extinção da punibilidade pela confissão e pagamento das contribuições, importâncias ou valores devidos à Previdência Social, antes do início da ação fiscal ${ }^{5}$. Dessa forma, a extinção da punibilidade pelo pagamento anterior ao recebimento da denúncia, nos termos do art. 34 da Lei 9.249/95, passa a não incidir sobre as contribuições previdenciárias, estando vigente tão somente quanto aos tributos federais (BRASIL, 2016e, online).

${ }^{5}$ Código Penal. Art. 168-A. (...) $\$ 2^{\circ}$. É extinta a punibilidade se o agente, espontaneamente, declara, confessa e efetua o pagamento das contribuições, importâncias ou valores e presta as informações devidas à Previdência Social na forma da lei ou regulamento, antes do início da ação fisca (BRASIL, 2016b, online).

Art. 337-A (...) $\$ \mathbf{1}^{\mathbf{0}}$. É extinta a punibilidade se o agente, espontaneamente, declara e confessa as contribuições, importâncias ou valores e presta as informações devidas à Previdência Social, na forma definida em lei ou regulamento, antes do início da ação fiscal. 
Já a Lei 10.684, de 30.05.2003, regulou as hipóteses de extinção da punibilidade pelo pagamento, indistintamente, de todas as espécies tributárias. Cabe destacar que "além dessa promoção da regularização de débitos, a lei trouxe dispositivos que tratam do pagamento como causa extintiva da punibilidade, do parcelamento como causa suspensiva da pretensão punitiva do Estado (...) as disposições penais aplicam-se a toda conduta relativa a pagamento de débito de tributo, a qualquer tempo" (LEMES, 2009, p.151). Veio também a previsão de suspensão da punibilidade do delito em estudo no caso e parcelamento do débito em qualquer tempo, seja no procedimento fiscal ou judicial.

Observa-se que a ação fiscal própria que é o marco para a extinção da punibilidade é a execução fiscal, na qual o fisco exerce seu direito de ação junto ao Poder Judiciário. O legislador concluiu que se o agente confessa e declara débito que não era de conhecimento do fisco é suficiente para extinguir a punibilidade, equiparando-a à confissão espontânea.

A extinção da punibilidade por meio da simples declaração ou confissão dos valores devidos pela prática da sonegação de contribuição previdenciária gera a exclusão da pena, o que traduz atalho para a descriminalização. A exclusão da punibilidade encontra guarida no fim político-arrecadatório e em relação à justificativa jurídico-penal, "a pena se faria desnecessária, uma vez que já estaria atingido seu escopo de prevenção geral e especial” (DI PIETRO, 1999, p. 74).

Esse nítido caráter arrecadatório da norma penal ou, melhor dizendo, a utilização do Direito Penal para incrementar coerção para estimular a arrecadação do Estado ameaça a possibilidade de condenação criminal do autor de crime contra a arrecadação da seguridade social e pode servir de inibidor da contribuição voluntária, sendo desestimulada ante a possibilidade de exclusão da pena pela simples declaração ou confissão dos valores devidos no curso do processo, ou pagamento em qualquer tempo.

Diante de todos os modos de cobrança administrativa e de constatação da sonegação de contribuição previdenciária por meio dos órgãos competentes, parece irrazoável que a única forma eficaz de não sonegação e consequente recolhimento de contribuição seja a ameaça da pena privativa de liberdade. Ademais, na sociedade contemporânea existe uma relativa falta de concretude das sanções penais. O reprodutor de condutas desviadas dificilmente atuaria nelas se tivesse certeza de que seria descoberto em seu ato delituoso e punido por ele. Segundo Jefferson Aparecido Dias, hoje (DIAS, 2007, p.31), 
se fiscalizada e apurada eventual irregularidade, a empresa poderá discutir administrativa e judicialmente se aqueles valores são devidos e, se ao final, se concluir que eles são efetivamente devidos, poderá parcelar o débito ou mesmo pagá-lo, total ou parcialmente, e usufruir as inúmeras benesses previstas na legislação para o criminoso previdenciário.

Agora, se pela simples declaração ou confissão dos valores devidos à previdência social antes do início da ação fiscal e pelo simples pagamento da dívida a qualquer momento, a conduta ilícita é perdoada, esquecidos todos os ardis perpetrados, e a punibilidade extinta sem consequências, não existe condenação, nem reincidência. Da mesma sorte, não haverá desabono de seus antecedentes. Nesse contexto, Daniel Alberto Casagrande (CASAGRANDE, Op. Cit., p. 63) entende que:

\begin{abstract}
o magistrado deixa de judicar e passa a atuar como mero coletor de valores, responsável por ajudar o Governo Federal a aumentar a arrecadação das contribuições. O Ministério Público, nesta linha de raciocínio, funciona quase que figurativamente, apenas chancelando o pagamento realizado. $\mathrm{O}$ ato de pagar não se reveste de qualquer sentido ético, e o acusado pode, quantas vezes entender, valer-se do mesmo expediente. Não há contra isso qualquer repreensão legal, já que se trata de gozo de direito legalmente previsto.
\end{abstract}

Cabe aduzir que outros crimes de pequena monta e de insignificante repercussão social não tem sua punibilidade extinta pela recomposição do status quo. Aquele que furta um computador, caso devolva o bem, se tiver reconhecido a seu favor o arrependimento posterior, poderá ser agraciado, no máximo, com a diminuição da pena. Além disso, perde a primariedade depois de passar como acusado todo o processo penal.

Ora, a extinção da punibilidade pela simples declaração ou pagamento demonstra que o Direito Penal não deveria ser o principal instrumento formal de controle social neste caso, sendo um caminho obtuso à descriminalização posto que a finalidade do Governo não é a punição criminal em si, mas a arrecadação ao Sistema de Custeio Social.

Destarte, o agente do crime em estudo viola também o disposto no art. 225 do Decreto 3.038/99, que obrigada à empresa a "preparar folha de pagamento da remuneração paga, devida ou creditada a todos os segurados a seu serviço" e "informar mensalmente ao Instituto Nacional do Seguro Social, por intermédio de documento a ser definido em regulamento, dados relacionados a fatos geradores de contribuição previdenciária e outras informações de interesse do INSS" (PRADO, 2004, p. 53). 
A questão da relevância deste tipo penal encontra crítica na evidente instrumentalização do Direito Penal em razão de interesses basicamente fiscais arrecadatórios. A fundamentação seria a de que o comportamento indica ser desnecessária a imposição da pena, porque os fins preventivos da sanção penal já foram alcançados (CARVALHO, 2001, p. 263).

Entretanto, como já dito, no Estado Democrático de Direito, uma intervenção penal legitimada somente se justifica na dupla compreensão da missão do Direito Penal: a pena deve cumprir uma missão política de regulação da vida social que assegure seu funcionamento satisfatório, mediante a proteção dos bens dos cidadãos. A concretização da missão depende da função de prevenção que o próprio Direito Penal estabelece, de modo que a prevenção se limite estritamente aos princípios que regem um Estado Democrático de Direito, quais sejam, a proteção de bens jurídicos e proporcionalidade (SUXBERGER, Op. Cit., p. 165). Diante disto, é fundamental refletir se é razoável ou é proporcional a utilização do Direito Penal para os fins arrecadatórios de que tratam o crime de sonegação da contribuição previdenciária.

Além da extinção da punibilidade, existe o perdão e aplicação exclusiva de multa nos crimes previdenciários, tais figuras estão em vigor em relação aos crimes nos quais o resultado corresponde ao não pagamento de contribuições sociais de até determinado valor, sendo que este depende do momento do fato ${ }^{6}$. Atualmente vigora a Lei 10.522/2002, que determina o arquivamento de execuções fiscais da União inferiores a $\mathrm{R} \$ 10.000,00$ (dez mil reais $)^{7}$.

\section{ADEQUAÇÃo E NECESSIDAdE DA TUTELA PENAL NO CRIME DE SONEGAÇÃO DE CONTRIBUIÇÃO PREVIDENCIÁRIA}

\footnotetext{
${ }^{6}$ Por exemplo, o Memorando Circular/INSS/PG/36 de 22.11.1998 estipulava o limite mínimo de R\$ 5.000,00 (cinco mil reais) para o ajuizamento de execuções fiscais pelo INSS.

7 “Art. 20. Serão arquivados, sem baixa na distribuição, mediante requerimento do Procurador da Fazenda Nacional, os autos das execuções fiscais de débitos inscritos como Dívida Ativa da União pela ProcuradoriaGeral da Fazenda Nacional ou por ela cobrados, de valor consolidado igual ou inferior a R \$10.000,00 (dez mil reais)" (BRASIL, 2016f, online). Esse valor consta também da Portaria MF 49, de 01.04.2004, que determina o não ajuizamento de débitos para com a Fazenda Nacional que sejam inferiores a R \$10.000,00 (dez mil reais).
} 
O sistema penal é pensado para decidir quem merece a imputação da sanção, ou seja, da pena. O Direito Penal estabelece conceitos e delimita a tipicidade dos fatos visando, mormente, o controle social. Nessa esteira, Santiago Mir Puig (2007, p. 33) afirma que:

O Direito penal constituiu um dos meios de controle social existentes na sociedade atual (...) Como todo meio de controle social, o Direito tende a evitar determinados comportamentos sociais considerados indesejáveis, recorrendo, para isso, à ameaça de imposição de distintas sanções, caso tais condutas sejam realizadas” (...)

A norma penal "não surge da crença singela de que determinada conduta deve ser punida, porém da real necessidade de se tutelar o bem pretendido de uma forma socialmente mais severa, mais rígida, mais incisiva e também mais enérgica e violenta, posto que a pena atinge o valioso direito de liberdade (IBAIXE JUNIOR, 2003, p. 549-551).

É verdade que, tratando-se de Direito Penal, queda-se muitas vezes indispensável a tipificação de condutas violadoras de interesses da coletividade, mormente no caso da Previdência onde se tutela não somente o produto da arrecadação (patrimônio), mas também na função social desempenhada.

Para Rios (1998, p. 41 e 50), ao partir do conceito de bem jurídico como "unidade funcional", descrito por Jakobs, explica-se como o Estado pode punir condutas fraudulentas nas prestações públicas que visem obstaculizar o cumprimento de suas funções, concluindo que:

\footnotetext{
A justificação do crime fiscal encontra-se no fato de que a conduta delituosa, além de causar um prejuízo imediato à integridade patrimonial do Erário Público (lesando a função pública de arrecadação), acaba por atingir o valor constitucional da solidariedade de todos os cidadãos, na contribuição da manutenção dos gastos públicos. Este bem jurídico, 'representado' nas funções que o tributo deve exercer de acordo com os dispositivos constitucionais, justifica amplamente sua incriminação (Idem).
}

Já Alexandre Barbosa Lemes (299, p. 51) argumenta que a própria finalidade instrumental do sistema tributário legitimaria a intervenção penal em prol da dignidade da pessoa, mas somente nos casos envolvendo condutas mais graves e bens jurídicos mais relevantes não tutelados. Essa ligação à dignidade da pessoa humana envolve o meio de distribuição de riquezas entre as camadas sociais e entre as regiões do país, como realizadora 
da política socioeconômica por meio da extrafiscalidade e como instrumento de receita para a manutenção da máquina estatal visando à segurança interna e externa e às prestações sociais.

Neste sentido, disciplina Antonio Suxberger que o bem jurídico configura um valor da ordem social juridicamente protegido e existem influências culturais nesta definição. Despojando-se de seu conteúdo material, o bem jurídico constitui-se hoje somente em um valor para a interpretação dos tipos penais. Assim, alguns interesses podem transformar-se em condições sociais valiosas, razão pela qual podem ser tidas como bens jurídicos, para que o Estado proteja algumas prestações de caráter público pela grande relevância que tem para a criação de condições dignas de vida. É o mesmo caso da tutela da administração da justiça, fidelidade de documentos e meio ambiente equilibrado (Op. Cit., p. 172-173 e 180).

Destoando desse pensamento, Bello Filho (1996, p.474) aduz que "a razão de ser da norma questionada não é tornar-se mais um meio de pressão sobre o devedor para satisfação do crédito tributário do Estado". Mesmo sendo legítima a tutela penal previdenciária, a sua necessidade é questionável, diante da intervenção mínima, todavia, há entendimento de que a criminalização de determinadas condutas respeita o caráter de ultima ratio do Direito Penal quando se denota que as sanções dos outros ramos do Direito mostrem-se insuficientes ou inadequadas (RIOS, 2001, p. 15).

Há entendimento de que a importância deste tipo penal pode embasar-se na "demanda funcional de um bem jurídico supraindividual de natureza econômica" (Ibidem, p. 18). O crime se consuma na data em que o agente está obrigado legalmente a apresentar a guia disposta no art. 225 do Decreto 3.048/99 e não o faz. Omitir folha de pagamento ou documento de informação, omitir lançamento contábil nos títulos próprios da contabilidade da empresa as quantias descontadas dos segurados ou as devidas pelo empregador ou pelo tomador de serviços. Por fim, omitir, total ou parcialmente, receitas ou lucro auferidos, remunerações pagas ou creditadas e demais fatos geradores de contribuições sociais previdenciárias.

A pena prevista é de reclusão de dois a cinco anos, e multa e a ação penal pública é incondicionada. Assim, as condutas incriminadas no tipo são um crime meio, ou seja, a conduta realizada pelo agente para alcançar o resultado é, de per si, um delito (falsidade ideológica). As contribuições que ensejam o crime podem ser as protegidas pelo art. 168-A do Código Penal como também, outras, de obrigação do responsável pela empresa que incide no fato gerador do tributo. 
Ora, a tipificação das condutas, justifica-se normalmente em razão da dignidade penal do bem jurídico tutelado. Há também a justificativa de ausência de sanções civis e administrativas para proteção desses bens. Alexandre Barbosa Lemes argumenta que embora a previsão das causas de extinção da punibilidade obedeça a motivos de razão políticocriminal, "não se pode admitir que essas razões sejam sobrepostas por interesses funcionalistas, meramente arrecadatórios" (LEMES, Op. Cit., p. 149). Aduz ainda que isso seria um desmerecimento do Direito Penal, que assim não cumpre suas funções e desprestigiam-se as penas previstas e não impostas, o que sugere à sociedade que as sanções penais não precisam ser cumpridas.

\section{CONCLUSÃO}

O crime de sonegação fiscal previdenciária nos moldes apresentados no Código Penal traduz-se em instrumento simbólico de punição utilizado para controle de evasão das contribuições previdenciárias. $\mathrm{O}$ intento do legislador de resguardar a escorreita arrecadação de contribuições sociais previdenciárias acabou deturpando-se, pois, a mera declaração do valor devido antes do início da ação fiscal já extingue a punibilidade e a qualquer tempo pode-se efetuar o pagamento do montante devido, o que em nada inibe o infrator de voltar a delinquir.

Dessa feita, o tipo perde seu viés repressivo e punitivo, mostra finalidade de aumento da arrecadação tributária, realizada em detrimento dos princípios da intervenção mínima, da proporcionalidade e da isonomia. As condutas ofensivas ao custeio da seguridade social são 
embasadas por uma norma débil que admite exceção em afronta a diversos fundamentos do Direito.

A política fiscal e o argumento de que a prova da materialidade do crime em voga é e difícil constatação, não são escusas para a manutenção da norma nos termos hoje elencados, até porque o fisco tem meios de investigação, fiscalização e atuação contra a evasão fiscal, além de medidas judiciais de cobrança das contribuições sociais. Caso não houvesse a previsão de extinção de punibilidade nos termos já apresentados, o crime de sonegação de contribuição previdenciária ficaria a salvo do descrédito que atualmente se lhe imputa pela falta de efetividade, podendo atuar de forma mais incisiva no combate a evasão do sistema.

Inobstante, no crime de sonegação de contribuição previdenciária, tem-se que não existem fundamentos de política criminal que lhe retirem o caráter meramente simbólico, não se encaixando em premissas básicas tais como: manter a ordem social básica; incidir sobre um dos fatores decisivos na produção de tais prejuízos e neutralizar tais condutas através do controle social e dentro dele, do controle social penal. Nenhuma dessas três premissas para criação de normas penais justifica a tipificação da conduta descrita, tampouco, a previsão de extinção de punibilidade disposta ao crime, que queda-se mais em incentivo a sua prática que prevenção da conduta.

Para tal análise há que se distinguir entre os ilícitos tipicamente administrativos, meras faltas de recolhimento, ou delitos fiscais próprios. A fiscalização das empresas, aplicação de multas e demais sanções administrativas já tem o condão de prevenção de condutas lesivas à arrecadação previdenciária. Determinadas condutas demonstram o desvirtuamento do Direito Penal, onde o legislador adiciona pressão para o pagamento de tributos.

No crime de sonegação de contribuição previdenciária se exige o dolo, há previsão de conduta fraudulenta, como acontece nos crimes tributários comuns, o que difere do crime de apropriação indébita onde basta a omissão do recolhimento no prazo legal.

Todas as benesses pré-delitivas positivas atribuídas pelo legislador remetem a razões de política criminal em evidente disposição exclusiva da função arrecadatória do Estado, ou seja, existem condutas graves contra o fisco que são penalmente sancionadas, todavia, oferece-se ao agente criminoso a extinção da punibilidade sem sequer ser processado, mediante o pagamento do valor devido. E tal conduta denota o uso simbólico do Direito Penal, por meio do qual a necessidade de aumento da arrecadação estatal não é suprimida diante da função garantista que tutela a dignidade do ser humano. Há uma clara discrepância 
entre os fins pretendidos pelo Estado Democrático de Direito e os valores estabelecidos pela Constituição Federal, aos quais o Direito Penal deve se submeter, e os fins estabelecidos pela pena.

O legislador simplesmente operou um desvalor na ação criminosa, desconsiderou a reprovação social da fraude cometida na qual se embasava para justificar a tipificação da conduta e simplesmente determinou a extinção da punibilidade ao agente que paga sua dívida. Sendo assim, desnecessário o tipo, pois, administrativa e judicialmente o fisco já possuía e possui meios até mais eficazes que o tipo penal para a cobrança das contribuições sociais. Vêse uma desvalorização do Direito Penal e uma criminalização abusiva dando à sociedade a impressão de que aquele indivíduo com recursos para pagar suas dívidas não será processado criminalmente.

\section{REFERÊNCIAS}

ANDRADE, Pedro Ivo. Crimes contra as Relações de Consumo - Art. $7^{\circ}$. Da Lei 8.137/90. Curitiba: Juruá, 2007.

ATALIBA, Geraldo. Hipótese de Incidência Tributária.6.ed. São Paulo: Malheiros, 1999.

BALERA, Wagner. Crime Tributário de Apropriação Indébita. Repertório de Jurisprudência IOB, São Paulo, n. 4, fev. 1998.

BARBOSA, Alexandre Lemes. Tutela penal da previdência social. Curitiba: Juruá: 2009. p. 51.

BECCARIA, Cesare Bonesana. Dos Delitos e as penas. 2.ed. Tradução de José Cretella Junior e de Agnes Cretella. São Paulo: Revista dos Tribunais, 1997.

BELlO FILHO, Ney de Barros. Anotações ao Crime de não recolhimento de contribuições previdenciárias. Revista dos Tribunais. São Paulo: Revista dos Tribunais, v. 732, out/1996, p. 474.

BIANCHINI, Alice. Pressupostos materiais mínimos da tutela penal. São Paulo: Editora Revista dos Tribunais, 2002.

BRASIL. Constituição da República Federativa do Brasil de 1988. Disponível em: <http://www.planalto.gov.br/ccivil_03/Constituicao/Constituicao.htm>, acesso em: 26.mar.2016a. 
. Decreto-lei $n^{0}$ 2.848, de 7 de dezembro de 1940. Código Penal. Disponível em: <http://www.planalto.gov.br/ccivil_03/decreto-lei/Del2848compilado.htm>, acesso em 26.mar.2016b.

Lei $\mathbf{n}^{0}$ 5.172, de 25 de outubro de 1966. Dispõe sobre o sistema tributário nacional e institui normas gerais de direito tributário aplicáveis à União, Estados e Municípios. Disponível em: <http://www.planalto.gov.br/ccivil_03/leis/L5172.htm>, acesso em 24.set.2016c.

Lei $\mathbf{n}^{0}$ 8.212, de 24 de julho de 1991. Dispõe sobre a organização da seguridade social. Dispoível em: <http://www.planalto.gov.br/ccivil_03/leis/L8212cons.htm>, acesso em 24.set.2016d.

BRASIL. Lei $\mathbf{n}^{\circ}$ 9.249, de 26 de dezembro de 1995. Altera a legislação do imposto de renda das pessoas jurídicas, bem como da contribuição social sobre o lucro líquido, e dá outras providências. Disponível em: < http://www.planalto.gov.br/ccivil_03/leis/L9249.htm>, acesso em 24.set.2016e.

Lei 10.522/02, de 19 de julho de 2002. Dispõe sobre o Cadastro Informativo dos créditos não quitados de órgãos e entidades federais e dá outras providências. Disponível em: < http://www.planalto.gov.br/ccivil_03/leis/2002/L10522.htm>, acesso em 24.set.2016f.

CARVAlHO, Érika Mendes de. Punibilidade e fins da pena. Revista Dialética de Direito Tributário. São Paulo: Dialética, 2001.

CASAGRANDE, Daniel Alberto. Crimes contra a arrecadação da seguridade social: apropriação indébita previdenciária e sonegação de contribuição previdenciária. 2008. 129 f. Dissertação (Mestrado em Direito Penal) - Universidade de São Paulo, São Paulo, 2008 .

Crimes contra a arrecadação da seguridade social: apropriação indébita previdenciária e sonegação de contribuição previdenciária. São Paulo: Verbatim, 2010.

COELHO, Yuri Carneiro. Bem jurídico-penal. Belo Horizonte: Mandamentos, 2003.

COSTA JR. Paulo José. Direito Penal. Parte Geral.v. 1. 21. Ed. São Paulo: Atlas, 2004.

DIAS, Jefferson Aparecido. Crime de Apropriação Indébita Previdenciária. CP, art. 168A, § $1^{\circ}$, inc. I, 2.ed. Curitiba: Juruá, 2007.

DI PIETRO, Maria Sylvia Zanella. Direito Administrativo. 10. ed.São Paulo: Atlas, 1999.

IBAIXE JUNIOR, João. Crimes Previdenciários: garantismo penal e responsabilidade da pessoa jurídica. Revista de Previdência Social. São Paulo, a. XXVII, v.27, n. 272, jul. 2003.

LEMES, Alexandre Barbosa. Tutela penal da previdencia social. Curitiba: Juruá, 2009. 
LOPES, Maurício Antonio Ribeiro. Teoria constitucional do direito penal. São Paulo: Editora Revista dos Tribunais, 2000.

MESTIERI, João. Manual de Direito Penal. Parte Geral. v. 1. Rio de Janeiro: Forense, 1999.

MIR PUIG, Santiago. Direito Penal. Fundamentos e Teoria do Delito. Trad. Cláudia Viana Garcia e José Carlos Nobre Porciúncula Neto. São Paulo: RT, 2007.

PIERDONÁ, Zélia Luiza. Contribuições para a Seguridade Social. São Paulo: LTr, 2003.

PRADO, Luiz Regis. Apontamentos sobre a punibilidade e suas condicionantes positiva e negativa. Revista dos Tribunais. São Paulo: Revista dos Tribunais, 2000. V. 776.

Luiz Regis. Direito Penal Econômico. São Paulo: Revista dos Tribunais, 2004.

Luiz Régis. Curso de Direito Penal Brasileiro. V. 4. Ed. São Paulo: RT, 2006.

RIOS, Rodrigo Sánchez. O Crime Fiscal. Porto Alegre: Sergio Antonio Fabris, 1998.

Tutela Penal da Seguridade Social. São Paulo: Dialética, 2001.

Das Causas de Extinção da Punibilidade nos Delitos Econômicos.

São Paulo: RT, 2003.

SUXBERGER, Antônio. A intervenção penal como reflexo do modelo de Estado: a busca por uma intervenção penal legítima no Estado Democrático de Direito. 2005. 217 f. Dissertação (Mestrado em Direito) - Universidade de Brasília, Brasília, 2005.

ZAFFARONI, Eugenio Raúl; PIERANGELI, José Henrique. Manual de Direito Penal Brasileiro: parte geral. 5. ed. São Paulo: Revista dos Tribunais, 2004. 